\title{
Hereditary orotic aciduria
}

INSERM

\section{Source}

INSERM. (1999). Orphanet: an online rare disease and orphan drug data base. Hereditary orotic aciduria. ORPHA:30

Hereditary orotic aciduria is an extremely rare (less than 20 cases identified worldwide) autosomal recessive disorder characterized by retarded growth, anemia and excessive urinary excretion of orotic acid. It is due to a severe deficiency in the activity of the pyrimidine pathway enzyme uridine 5'-monophosphate (UMP) synthase (bifunctional enzyme containing two activities: orotate phosphoribosyltransferase and orotidine 5'monophosphate decarboxylase), coded by a single gene (UMPS) localized to chromosome 3q13. 